\title{
Penerapan Agrarische Wet (Undang-Undang Agraia) 1870: Periode Awal Swastanisasi Perkebunan Di Pulau Jawa
}

\author{
Masyrullahushomad ${ }^{1}$ Sudrajat ${ }^{1}$ \\ ${ }^{1}$ Afiliasi (Program Studi Pendidikan Sejarah Pascasarjana Universitas Negeri Yogyakarta, Jalan \\ Colombo No. 1 Yogyakarta 55281, Indonesia) \\ Shomadsejarah2013@gmail.com, sudrajat@uny.ac.id
}

Received 25 June 2019; Received in revised form 20 July 2019; Accepted 24 August 2019

\begin{abstract}
Abstrak
Perkembangan perkebunan di Indonesia terbagi menjadi dua fase. Fase pertama disebut dengan fase perkebunan negara (1830-1870). Sedangkan, fase kedua adalah fase perkebunan swasta yakni fase pasca diterapkannya Agrarische Wet 1870 (Undang-Undang Agraria). Agrarische Wet 1870 menjadi landasan yuridis formil masuknya investasi swasta non pemerintah dalam industri perkebunan di Hindia Belanda. Dampak langsung dari diterapkannya Agrarische Wet 1870 adalah meningkatnya intensitas jumlah ekspor komoditas perkebunan dan semakin bertambah luasnya lahan perkebunan besar di Hindia Belanda khususnya di Pulau Jawa.

Kata Kunci:Agrarische Wet 1870, swasta, perkebunan.
\end{abstract}

\begin{abstract}
The development of plantations in Indonesia is divided into two phases. The first phase is called the state plantation phase (1830-1870). Meanwhile, the second phase is the private plantation phase, the phase after the implementation of the Wet Agrarische 1870 (Agrarian Law). The Wet 1870 Agrarische became the formal juridical foundation for the entry of non-government private investment in the plantation industry in the Indies. The direct impact of the implementation of the Wet Agrarische 1870 was the increasing intensity of the number of plantation commodity exports and the increasing breadth of large plantation land in the Dutch East Indies, especially in Java.
\end{abstract}

Keywords: 1870 Agrarische Wet, private, plantation.

\section{PENDAHULUAN}

Pasca kerja paksa, sistem politik dan kebijakan pertanahan memasuki babak baru, yakni era ekonomi liberal berlaku di Hindia Belanda. Pada periode ini, perdebatan di parlemen Belanda tentang investasi perkebunan skala luas kemudian menghasilkan Regering Reglement (Agrarische Wet 1870). Sistem monopoli pemerintah kolonial selama ini tentang tanah didesak oleh swasta agar pihak swasta diberi ruang untuk melakukan investasi di Hindia Belanda. Hasilnya keluarlah Agrarische Wet 1870 (Undang-Undang Agraria) (Salim, 2014: 18-19).

Sekilas, lahirnya Agrarische Wet 1870, seolah memberi kabar gembira kepada rakyat pribumi karena rakyat pribumi akan diberikan hak eigendom. Akan tetapi, Agrarische Wet 1870 hanyalah alasan untuk memuluskan jalan pemodal asing untuk berinvestasi di Indonesia. Keuntungan yang besar 
hanya dinikmati oleh para pemodal asing, sementara rakyat pribumi hidupnya semakin merana (Anggraini, 2016: 45-46).

Sejak diberlakukannya Agrarische Wet 1870, pengusahapengusaha perkebunan Belanda dan negara Eropa lainnya mendapatkan jumlah keuntungan yang luar biasa dengan berlandaskan pada colonial super profit. Istilah ini mengacu pada kondisi akumulasi modal luar biasa dari investasi modal asing yang mendapatkan tenaga kerja dengan jam kerja yang panjang dan upah yang rendah. Di samping itu, pihak pemodal tidak perlu menanggung beban pembangunan infrastruktur seperti fasilitas transportasi dan komunikasi. Semuanya dibiayai oleh pemerintah yang diambil dari pungutan pajak oleh pemerintah terhadap penduduk negeri jajahan (Achdian, 2008:20).

Pemberlakukan Agrarische Wet 1870 selama lebih dari 70 tahun (18701942), menjadi landasan legal-politis pemerintah kolonial Belanda dalam memfasilitasi perusahaan-perusahaan kapitalis Eropa dengan hakerfpachtrecht selama 75 tahun (Rachman, 2012: 15).

Selama periode antara 1870 hingga 1942 perkembangan modal swasta dalam sektor perkebunan pasca pemberlakuan Agrarische Wet 1870 mendominasi perekonomian di Hindia Belanda. Beberapa komoditi utama perkebunan besar di Hindia Belanda khususnya di Pulau Jawa adalah gula, kopi, tembakau, teh, kareta, kina, dan kelapa. Sedangkan, di luar Pulau Jawa adalah karet, kelapa sawit, dan tembakau merupakan produk utamanya (khususnya di Sumatera). Dalam periode ini, komoditi gula mulai menggantikan kedudukan kopi sebagai primadona produk unggulan yang diproduksi di Pulau Jawa. Berdasarkan analisis tersebut, maka artikel ini akan membahas sejarah lahirnya Agrarische Wet 1870 dan hubungannya dengan swastanisasi perkebunan di Indonesia khususnya di Pulau Jawa.

\section{METODE}

Kajian ini dilakukan dengan menggunakan metode sejarah yang mencakup empat tahap, yakni: heuristik (heuristik), kritik sumber (verifikasi), interpretasi (oufassung), dan historiografi (darstellung) (Abdurrahman, 2011: 104). Sumbersumber dalam kajian ini menggunakan data-data sekunder yang relevan dengan objek pembahasan. Sumber sekunder adalah dokumen yang menguraikan atau membicarakan sumber primer. Katagori sumber sekunder adalah monografi, buku-buku pelajaran, hasil kongres, makalah, prasaran, dan lain-lain (Marzuki, 2014: 36). Sumber-sumber tersebut didapatkan dari beberapa perpustakaan, google book, dan jurnal- 
HISTORIA: Jurnal Program Studi Pendidikan Sejarah Volume 7 (2) 2019

ISSN 2337-4713 (E-ISSN 2442-8728)

jurnal resmi yang bisa diakses di internet.

\section{PEMBAHASAN}

\section{LAHIRNYA AGRARISCHE WET 1870}

Sistem perkebunan di Indonesia telah hadir sejak era pendudukan kolonial Hindia Belanda. Keberadaan perkebunan kolonial tidak lepas dari pasang-surutnya dinamika ekonomi-politik di negeri Belanda. Sebagai wilayah jajahan Belanda, di Indonesia pada waktu itu dikenal dua sistem perkebunan yang menonjol, yaitu sistem perkebunan “negara" (1830-1870) dan sistem perkebunan swasta "liberal" (pasca 1870). Pada sistem yang pertama pemerintah lebih banyak menggunakan otoritasnya (high authority) untuk membeli berbagai komoditi yang diperlukan dan tidak jarang dengan cara-cara paksa.

Selanjutnya, pada sistem perkebunan swasta "liberal" terjadi hubungan ketergantungan yang erat antara pusat-pusat perkebunan dengan pusat-pusat metropolitan dengan pasar modalnya. Besarnya aliran investasi yang bebas dan luas menurut catatan Gordon telah menempatkan Belanda sebagai negara investor terbesar nomor 3 (tiga) di dunia yang sebagian besar investasinya ditanamkan di Hindia Belanda. Liberalisasi perkebunan ini tidak dapat dilepaskan dari tuntutan para pemilik modal perkebunan. Seperti yang dikatakan Pelzer bahwa karena ketergantungan pemerintah Belanda terhadap perkebunan sebagai sumber devisa utama. Menyebabkan Pemerintah Belanda terpaksa menyerah terhadap tuntutan pihak pemilik modal perkebunan (Tim Riset Sistematis STPN, 2010: 50).

Upaya untuk melakukan swastanisasi perkebunan di Hindia Belanda sebenarnya telah berlangsung sejak masa pemerintahan Menteri Jajahan Frans van de Putte. Pada tahun 1865, Menteri Jajahan Frans van de Putte (seorang liberal) mengajukan sebuah Rencana Undang-Undang (RUU) yang menyatakan bahwa: (1). Gubernur Jenderal akan memberikan hal erfpacht (hak guna usaha) selama 99 tahun, (2) Hak milik pribumi akan diakui sebagai hak mutlak (eigendom), dan (3) Tanah komunal dijadikan hak milik perorangan sebagai hak mutlak (eigendom). Ternyata RUU ini ditolak oleh parleman bahkan ditentang keras oleh sesama golongan liberal sendiri dengan tokoh utamanya Thorbecke. Tidak hanya itu, Menteri Jajahan Frans van de Putte akhirnya dijatuhkan dari jabatannya karena dianggap terlalu tergesa-gesa memberikan hak eigendom kepada pribumi. Sampai saat itu tujuan golongan swasta Belanda untuk menamkan modal di bidang pertanian di Hindia Belanda belum tercapai (Wiradi, 2000: 126-127). 
Setelah jatuhnya Menteri Jajahan Frans van de Putte dari tampuk jabatannya sebagai Menteri Jajahan. Pada tahun 1866/1867, pemerintah jajahan mengadakan penelitian tentang hak-hak penduduk Jawa atas tanah yang dilakukan di 808 desa di seluruh Jawa. Laporan penelitian ini terbit dalam tiga jilid pada tahun 1876, 1880, dan 1890 dengan judul Eindresume van het Onderzoek naar de Rechten van den Inlander op de Grond (biasa disingkat: Eindresume). Ternyata pemerintah Belanda tidak sabar menunggu hasil penelitian ini. Pada tahun 1870, Menteri Jajahan de Waal mengajukan RUU ke parlemen. Isinya terdiri dari 5 ayat. Kelima ayat ini kemudian ditambah 3 ayat dari pasal 62 RR tersebut di muka, sehingga menjadi 8 ayat, di mana satu diantaranya menyebutkan bahwa Gubernur Jenderal akan memberikan hak erfpacht selama 75 tahun (bukan lagi 99 tahun) seperti dalam RUU van de Putte yang sebelumnya ditolak Parlemen.

Pasal 62 RR dengan 8 ayat ini kemudian menjadi Indische Staatsregeling (IS) yang diundangkan dalam Lembaran Negara (Staatsblad) No. 188 tahun 1870. Ketentuanketentuan tersebut dalam pelaksanaannya diatur dengan berbagai peraturan dan keputusan. Salah satu keputusan penting ialah apa yang dikenal dengan Agrarisch Besluit yang diundangkan dalam Staatsblad No. 118 tahun 1870. Pasal 1 dari Agrarisch Besluit inilah yang memuat suatu pernyataan penting yang telah cukup dikenal yaitu Domain Verklaring, yang menyatakan bahwa "semua tanah yang tidak terbukti bahwa atas tanah itu ada hak milik-mutlak (eigendom) adalah domain negara (domain negara maksudnya milik negara)". Agrarisch Besluit 1870 inilah menjadi tonggak penting swastanisasi perkebunan di Hindia Belanda (Wiradi, 2000: 126-127).

Undang-undang Agraria yang lahir pada 9 April 1870 yang menjadi pasal 51 dari Wet op de Indische Staatsregeling, isinya sebagai berikut:

1. Gubernur Jenderal tidak boleh menjual tanah,

2. Larangan itu tidak mengenai tanahtanah kecil untuk perluasan kota dan desa untuk mendirikan perusahaan dan bangunan,

3. Gubernur Jenderal dapat menyewakan tanah yang diatur dalam undang-undang. Dalam peraturan ini tidak termasuk tanah yang telah dibuka oleh rakyat Indonesia atau dipergunakan untuk tempat menggembala ternak bagi umum atau yang masuk dalam lingkungan desa untuk keperluan umum lainnya,

4. Dengan undang-undang akan diberikan tanah-tanah dengan hak 
HISTORIA: Jurnal Program Studi Pendidikan Sejarah Volume 7 (2) 2019

ISSN 2337-4713 (E-ISSN 2442-8728)

pakai turun-temurun untuk selamalamanya 75 tahun,

5. Gubernur Jenderal menjaga agar jangan sampai pemberian tanah itu melanggar hak-hak rakyat Indonesia,

6. Gubernur Jenderal tidak boleh mengambil tanah-tanah yang telah dibuka oleh rakyat Indonesia untuk keperluan mereka sendiri, atau untuk keperluan lain kecuali untuk kepentingan umum berdasarkan pasal 133 I.S., dan untuk keperluan perkebunan yang diselenggarakan oleh pemerintah menurut peraturan-peraturan yang berlaku untuk itu; semuanya itu dengan pemberian ganti rugi yang layak,

7. Tanah-tanah yang dimiliki oleh rakyat Indonesia dapat diberikan kepadanya dengan hak eigendom, dengan syarat-syarat dan pembatasan yang diatur dalam undang-undang, dan harus tercantum dalam surat tanda eigendom itu, yaitu mengenai kewajiban-kewajiban pemilik tanah kepada negara dan desa, dan juga tentang hak menjualnya kepada orang yang bukan orang Indonesia,

8. Persewaan tanah oleh rakyat Indonesia kepada orang asing berlaku menurut undang-undang.

Seterusnya dalam undang-undang itu termasuk juga hak-hak baru atas tanah, di antaranya disebutkan:
1. Pemberian hak erfpacht atas tanah yang berupa hutan belukar;

2. Perlindungan hak rakyat Indonesia atas tanah;

3. Membuka kemungkinan bagi rakyat Indonesia untuk mendapatkan hak yang lebih kuat atas tanahnya;

4. Persewaan tanah oleh bangsa Indonesia kepada bangsa asing.

Maksud yang terkandung dalam undang-undang itu menyatakan:

1. Menjamin kepentingan modal besar partikeliryang akan menanamkan modalnya di lapangan pertanian dan perkebunan dengan memberi kesempatan kepada modal besar partikelir untuk mendapatkan tanah dengan jaminan dan perlindungan akan perkembangannya,

2. Melindungi hak milik rakyat atas tanah sebagai golongan yang lemah dari akibat no. 1 di atas, dengan memberi kesempatan kepada rakyat Indonesia untuk mendapatkan hak agraris eigendom atas tanahnya sebagai hak yang lebih kuat, serta perlindungan dengan Undangundang agar jangan sampai tanahnya itu gampang jatuh ke tangan orang asing. Isi dua maksud dari Undang-undang di atas sangat bertentangan antara yang satu dengan yang lain.

Dari dua maksud tersebut dapat ditarik benang merahnya yaitu harus mengorbankan salah satu di antaranya. 
Keduanya merupakan pilihan yang cukup sulit, ibaratnya memelihara harimau dan kambing dalam satu kandang. Harimau harus gemuk, kambing perlu hidup dan jangan mati (Tauchid, 2009: 24-26)

Salah satu inti perundangan tersebut, Domein Verklaring, merupakan langkah awal yang radikal dalam mengusahakan sentralisasi penguasaan tanah dan sumber daya lain ke tangan negara secara faktual. Ekonomi Belanda saat itu telah siap untuk ekspansi modalnya secara mendiri, tidak lagi diwakilkan pada negara kolonial seperti sebelumnya, di daerah kolonial. Kawasan yang dianggap bebas kepemilikan, terutama daerah dataran tinggi, di definisikan sebagai tanah negara dan dapat disewakan pada swasta selama 75 tahun. Di dataran rendah swasta dapat menyewa tanah dari penduduk. Perkebunan tanaman keras bermunculan, dan kawasan tanam paksa (seperti daerah tebu) sedikit demi sedikit beralih dari negara ke tangan swasta.

Intervensi radikal dari negara (kolonial) ke dalam sistem penguasaan tanah dan produksi masyarakat sejak awal telah berdampak besar pada kehidupan rakyat di desa maupun kelembagaan pemerintahan pedesaan. Penelitian dari pemerintah Belanda sendiri memperlihatkan peningkatan kemiskinan di antara penduduk desa. Studi-studi dari Boeke yang melontarkan pengertian ekonomi dualistik dan statik expansion lepas dari penilaian terhadap pengertian-pengertian di atas mengindikasikan kemandekan ekonomi rakyat.

Demikian pun konsep involusi pertanian dari Geertz mengindikasikan berkurangnya tanah bagi petani dan pemiskinan. Daya jangkau dan teknologi saat itu tidak memungkinkan negara (kolonial) dan pemodal besarnya saat itu cepat berekspansi keseluruh kawasan Indonesia. Hanya beberapa enklave, seperti Sumatera Timur/Deli, menyaksikan ekspansi kapital dalam bentuk perkebunan-perkebunan tembakau dan berakibat pada penggusuran tanah-tanah penduduk diprakarsai oleh penguasa pribumi yang mempunyai kepentingan sama dengan pekebun-pekebun asing. Di segi lain, ekspansi negara (kolonial) ini berdampak pada kebutuhan sistem pemerintahan yang langsung. Terutama di Jawa, pemerintahan desa berkembang menjadi bagian integral dari pemerintah pusat (kolonial), mengabdi dan loyal pada kepentingan pemerintahan pusat (kolonial) dan modal besar (Shohibuddin, 2012: 45-46). Vollenhoven (2013: 166-167) menyatakan bahwa prinsip-prinsip yang ditetapkan dalam Agrarische Wet 1870 dituangkan rinciannya dalam keputusankeputusan agraria atau Agrarisch Besluit yang hanya berlaku di Jawa dan Madura. 
HISTORIA: Jurnal Program Studi Pendidikan Sejarah Volume 7 (2) 2019

ISSN 2337-4713 (E-ISSN 2442-8728)

Inti dari Agrarisch Besluit dijabarkan

dalam Staatsblad 1870 No. 118, dan produk-produk selanjutnya berisi perubahan berbagai pasal dari Staatsblad 1870 No. 118 itu. Yang termasuk keputusan agrarian adalah:

Statasblad 1870 No. 118

Staatsblad 1872 No. 116

Staatsblad 1874 No. 78

Staatsblad 1877 No. 196 dan 270

Statasblad 1888 No. 78

Staatsblad 1893 No. 151

Staatsblad 1893 No. 199

Staatsblad 1896 No. 140

Staatsblad 1904 No. 325

Staatsblad 1910 No. 185

Staatsblad 1912 No. 235

Staatsblad 1916 No. 647 dan 683

Staatsblad 1926 No. 321

Staatsblad 1935 No. 118 jo

Staatsblad1937 No. 339

Domeinverklaring dinyatakan
dalam Agrarische Besluit Staatsblad 1870 No. 118 dan berlaku untuk Jawa dan Madura. Untuk wilayah di luar Jawa dan Madura secara umum, domeinverklaring dinyatakan dalam Staatsblad 1875 No. 199a. Dan untuk wilayah-wilayah khusus, adalah sebagai berikut:

Sumatra: Staatsblad 1874 No. $94 f$ Manado: Staatsblad 1877 No. 55

Kalimantan Selatan/Timur:

Staatsblad 1888 No. 58

\section{DAMPAK DARI DIBERLAKUKANNYA} AGRARISCHE WET 1870

Pada era ini, semua tanah tak bertuan atau tanah kosong dikuasai oleh negara, sehingga negara bertindak sebagai dominum (pemilik tanah). Hal ini dimungkinkan supaya negara dapat menjual hak penguasaan tanah kepada swasta. Ketentuan ini dituangkan di dalam Pasal 1 Agrarische Besluid tahun 1870 yang mengatur mengenai asas domein verklaring, dengan ketentuan bahwa semua tanah yang tidak dapatdibuktikan dengan hak eigendomnya adalah domein negara (Wodowati, 2014 15).

Bertolak dari kepentingan politik keagrariaan Belanda di Hindia Belanda, maka negara harus dijadikan pemilik tanah tertinggi. Dasar pemikirannya adalah karena daerah jajahan telah ditaklukkan secara militer sehingga menjadi 'daerah taklukkan' (gekongcuesteert gebied) maka tanahnya pun menjadi 'tanah taklukkan' (agri limitati-Lat.). Berdasarkan kenyataan itu, negara bisa menjadi pemilik tanah tertinggi atas 'tanah taklukkan'. Dasar hukumnya untuk daerah jajahan, kemudian dirumuskan dalam Pasal 1 Agrarische Besluit 1870 yang merupakan penjelasannya Agrarische Wet 1870 (Undang-Undang Agraria 1870). Dalam Pasal 1 Agrarische Wet 1870 itu ditegaskan bahwa seluruh tanah adalah milik negara 
(landsdomein), kecuali dapat dibuktikan dengan bukti hak milik 'eigendom' berdasarkan Pasal 570 KUHPInd. Dengan demikian, struktur kepemilikan tanah di daerah jajahan yang diteruskan oleh pemerintahan negara Hindia Belanda adalah hanya mengenal dua subjek hukum pemegang hak milik 'eigendom' atas tanah yaitu negara dan orang sebagai pribadi hukum, seperti tampak dalam Diagram No. 3 berikut.

\section{Diagram Struktur pemilikan hak milik ‘eigendom’ di Hindia Belanda}

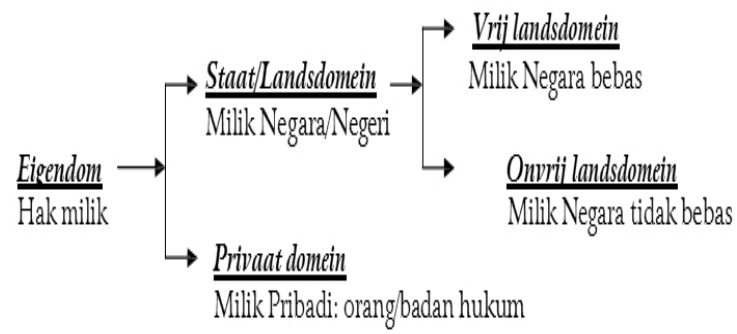

Sumber: Abstraksi Herman Soesangobeng dari BW/KUHPInd. dan Agrarische Wet 1870.

Diagram no. 3 ini menjelaskan bahwa hak milik tanah yang sah secara hukum hanyalah hak eigendom yang diatur dalam asal 570 BW/KUHPdt. Demikian pula subjek pemegang haknya pun hanya warga negara Belanda dan orang Eropa yang tunduk pada hukum sipil Belanda (BW/KUHPdt.). Negara sebagai subjek hukum baik dalam arti 'corpus comitatus' maupun 'corpus corporatum' adalah 'pemilik tertinggi' (het hoogste eigenar) atas seluruh tanah dalam wilayah Negara. Konsep kepemilikan tertinggi ini pada sistem hukum komon (common law system) di Amerika disebut 'right of eminent domein'. Dengan ketentuan ini maka pemerintah Hindia Belanda berhak dengan bebas mengambil kembali tanah miliknya yang dikuasai penduduk Bumiputra. Bila diperlukannya baik untuk keperluan negara maupun untuk diberikan kepada pengusaha swasta Belanda bagi pengembangan usaha pertanian atau perkebunan.

Karena sebelum VOC sampai terbentuknya pemerintahan Negara Belanda sudah ada penduduk-penduduk Indonesia yang menduduki dan menguasai tanah berdasarkan Hukum Adat mereka. Maka konsep tanah milik negara itupun lalu dibedakan antara tanah milik negara yang bebas ( $v r i j$ landsdomein) dan tanah negara yang tidak bebas (onvrij landsdomein). Tanah milik negara bebas adalah tanah-tanah milik negara yang tidak dilekati oleh hak-hak orang Bumiputra dengan hukum adatnya. Sebaliknya tanah negara tidak bebas adalah tanah milik negara yang diduduki dan dikuasai oleh orang Bumiputra berdasarkan hukum adat 
HISTORIA: Jurnal Program Studi Pendidikan Sejarah Volume 7 (2) 2019

ISSN 2337-4713 (E-ISSN 2442-8728)

mereka, sehingga hak adat orang Bumiputra masih melekat pada tanah milik negara (Soesangobeng, 2012: 8789).

Politik hukum pemerintah kolonial Belanda yang mempunyai pengaruh besar pada eksistensi tanah ulayat adalah diundangkannya Agrarisch Wet 1870 (Stb. 1870 No. 155)27, dengan peraturan pelaksanaannya Agrarisch Besluit 1870, yang memberlakukan asas domein dalam sistem penguasaan tanah. Pasal 1 AB 1870 berbunyi: "Behoundens opvolging van de tweede en derde bepaling der voormelde wet, blijft het beginsel gehandhaafd, dat alle grond, waaropniet door anderen recht van eigendom wordt bewezen, domein van de Staat is ("Dengan tidak mengurangi berlakunya ketentuan dalam Pasal 2 dan 3 Agrarisch Wet, tetap dipertahankan asas, bahwa semua tanah yang pihak lain tidak dapat membuktikan sebagai hak eigendomnya, adalah domein (milik) negara.

Pemberlakuan asas domein merupakan ide kaum kapitalis Belanda untuk mempermudah perolehan erfpacht dan opstal, sebab, menurut KUH Perdata, hanya pemilik (eigneaar) yang dapat memberikan hak-hak atas tanah kepada pihak lain. Dalam Agrarisch Wet, pemerintah bukan pemilik tanah sehingga berdasarkan asas domein, negara adalah pemilik semua tanah kecuali yang bisa dibuktikan sebagai eigendom dan agrarische eigendom". Domein Verklaring mengakibatkan tersubordinasinya sistem hukum asli Indonesia. Kata eigendom dalam Pasal 1 AB 1870 tersebut menimbulkan 3 (tiga) interpretasi: Pertama, tanah eigendom dapat diartikan menjadi tanah yang dalam hukum perdata disebut sebagai hak kepemilikan eigendom dan agrarisch eigendom. Kedua, karena eigendom dapat diterjemahkan sebagai kepemilikan, ini dapat berarti tanah dalam segala bentuk kepemilikan pribadi, termasuk hak-hak adat yang setara dengan kepemilikan, tetapi tidak termasuk hak (kepemilikan komunal) masyarakat adat yang disebut hak ulayat. Ketiga, ini dapat mencakup hak kepemilikan dalam hukum perdata dan hak-hak adat yang setara dengan kepemilikan termasuk hak ulayat. Pada praktiknya, interpretasi pertama yang dipakai (Sembiring, 2018: 88-90).

\section{KAKAKTERISTIK PERKEBUNAN SWASTA BERDASARKAN AGRARISCHE WET 1870}

Sistem perkebunan besar mulai hadir di Indonesia sebagai akibat politik liberal pemerintah kolonial Belanda melalui Agrarische Wet 1870. Dengan diberlakukannya Agrarische Wet 1870 (Undang-Undang Agraria) dan UndangUndang Gula (Suiker Wet) 1870 menjadi landasan mulai dibukanya perkebunan swasta di Pulau Jawa. Dibukanya 
perkebunan swasta menandai dimulainya kebijakan kolonial yakni dimulainya periode liberal (1870-1900). Sebelumnya monopoli pemerintah terhadap tanaman ekspor secara bertahap dihapuskan sejak 1860-an. Pertama kebijakan ini diberlakukan terhadap tanaman yang tidak menguntungkan dan terakhir tebu (akhirnya berakhir pada 1890) serta kopi (daerah terakhir yang menerapkan tanam paksa kopi baru ditutup pada 1919). Periode liberal bertepatan dengan ekspansi kekuasaan Belanda di luar Jawa. Eksploitasi perdagangan di pulau-pulau lainnya berlangsung selama abad ke-20. Akan tetapi, pada akhir abad ke-19 produk-produk dari pulaupulau di luar Pulau Jawa sudah masuk dalam kalkulasi perdagangan Belanda (Ricklefs dkk, 2013: 335-336 ; Kahin, 2013: 16-17).

Karakteristik sistem produksi perkebunan swasta pada masa ini umumnya mempunyai empat atribut yang melekat padanya, yaitu: pertama, berorientasi ekspor dalam skala besar; kedua, kebutuhan tenaga kerja sangat besar dibanding dengan yang dapat tersedia oleh pasar (tenaga kerja) domestik yang bebas; ketiga, diperlukan mekanisme ekstra-pasar (pemaksaan oleh aparatur pemerintah) guna memenuhi kebutuhan tersebut dan mekanisme ini sangat dominan dalam menentukan hubungan-hubungan sosial di dalam masyarakat; dan keempat, tumbuh budaya tertentu yang memperkuat hubungan-hubungan sosial yang terbentuk itu (Wiradi, 2009: 60).

Selain itu, berbeda dari kebijakan cultuurstelsel yang bertumpu pada dan memanfaatkan sistem desa. Agrarische Wet 1870 sebaliknya hendak melepaskan tanah dari ikatan-ikatan komunalnya pada desa dan membebaskan warga dari kerja wajib kepada desa. Pemerintah kolonial juga mengakui hak milik warga atas tanahnya dan melarang perpindahan hak milik itu kepada orang-orang asing. Namun, tujuan yang lain di balik itu sebenarnya adalah untuk memungkinkan pengusaha partikelir dapat menguasai tanah-tanah di luar tanah negara, yakni tanah-tanah garapan penduduk karena sekaligus akan dapat menguasai tenaga kerjanya. Hal ini dilakukan melalui kontrak sewa tanah kepada para petani pemiliknya dan merekrut mereka sebagai tenaga kerja perkebunan melalui sistem upahan (Shohibuddin, 2010: 36-37).

\section{PERKEMBANGAN PERKEBUNAN SWASTA DI JAWA}

Agrarische Wet 1870 (UndangUndang Agraria) memberikan kebebasan dan jaminan keamanan kepada para pengusaha (investor). Undang-undang ini menekankan pribumilah yang dapat memiliki tanah. Namun, orang-orang asing diperkenankan menyewanya dari 
HISTORIA: Jurnal Program Studi Pendidikan Sejarah Volume 7 (2) 2019

ISSN 2337-4713 (E-ISSN 2442-8728)

pemerintah selama 75 tahun atau dari para pemilik pribumi selama 5 sampai 20 tahun (tergantung persyaratan pada hak pemilikan tanah). Perkebunan swasta pasca diberlakukannya Agrarische Wet 1870 dapat berkembang di Pulau Jawa maupun di daerah-daerah luar Pulau Jawa. Pembukaan Terusan Suez pada tahun 1869 dan perkembangan pelayaran dengan kapal uap (sebagian berada di tangan orangorang Inggris) dalam waktu yang kirakira sama mendorong lebih lanjut perkembangan swasta dengan semakin membaiknya sistem perhubungan dengan Eropa (Ricklefs, 2008: 271).

Ekspansi besar-besaran perusahaan perkebunan dan pengusahaan tanaman perdagangan di Hindia Belanda terjadi antara 1870 dan 1920, terutama gula dan tebu di Jawa (termasuk juga teh dan kopi) dan kemudian karet dan kelapa sawit di Sumatera. Dalam kurun waktu ini, industri pertanian atau perkebunan di Hindia Belanda mengalami perkembangan yang sangat pesat. Meskipun di sisi lain terjadi penurunan setelah resesi 1884-1885, dengan perbaikan yang terjadi secara lambat pada dasawarsa 1890-an. Perkembangan prosfek perkebunan di Hindia Belanda terus berlangsung hingga meletusnya Perang Dunia I (Padmo, 1991:27).

Pasca diterapkannya Agrarische Wet 1870 di Pulau Jawa pemanfaatan lahan dimaksimalkan dengan sebaik mungkin. Daerah dengan demografi dataran tinggi digunakan untuk menanam kopi, teh, kina, dan ketela pohon di ladang-ladang. Sedangkan, di dataran rendah, perusahaan perkebunan menanam tebu, kakao, dan tembakau (Oudejans, 1999: 25-26). Perkembangan paling mencolok dari swastanisasi perkebunan di Pulau Jawa adalah perkembangan dalam industri gula (barang dagangan penting dari Hindia Belanda pada waktu itu). Dengan tersedianya modal swasta dalam jumlah besar. Perkebunan-perkebunan gula dan beberapa perkebunan lainnya dapat mengimpor mesin dan berbagai peralatan yang dapat meningkatkan produktifitas produksinya. Misalnya dalam hal perkebunan gula, perluasan lahan produksi dan kemajuan teknik produksi yang diintroduksi dalam industri ini menyebabkan kenaikan produksi yang pesat.

Dalam tahun 1870 luas tanah di Pulau Jawa yang ditanami gula berjumlah 54.176 bahu. Sedangkan dalam tahun 1900 jumlah itu meningkat menjadi 128.301 bahu. Di pihak lain, produksi gula meningkat lebih pesat lagi, yaitu dari 2.440.000 pikul dalam tahun 1870 meningkat menjadi 12.050.544 pikul dalam tahun 1900 . Demikian pula perkebunan-perkebunan teh mengalami perkembangan yang pesat, terutama setelah perusahaan- 
perusahaan perkebunan mulai ditanam dengan teh Assam. Tanaman ekspor lain yang mengalami kenaikan dalam produksi adalah tembakau. Jauh sebelumnya tembakau telah ditanam di daerah Yogyakarta dan Surakarta. Selama zaman liberalisme, pengusahapengusaha Belanda mendirikan pula perkebunan-perkebunan tembakaudi sekitar Basuki Jawa Timur yang kemudian mengalami perkembangan pesat.

\section{Perkebunan-perkebunan di}

Basuki tersebut bekerja sama erat dengan penduduk sekitar yang juga menanam tembakau yang kemudian disortir dan diolah selanjutnya di perkebunan-perkebunan besar. Di samping itu modal dan usaha Belanda mendirikan perkebunan-perkebunan tembakau yang besar di sekitar Deli Sumatera Timur. Tanaman-tanaman dagang lainnya yang dihasilkan perkebunan-perkebunan besar yang juga mengalami perkembangan pesat adalah kopi dan kina. Selama masa ini Hindia Belanda menjadi penghasil kina paling terkemuka di dunia karena hampir 90\% kina yang digunakan di dunia pada waktu itu berasal dari perkebunanperkebunan kina di Jawa. Di pihak lain, kopi tidak mengalami perkembangan begitu pesat selama seperti selama sistem tanam paksa berlaku (Poesponegoro, 2008: 377).
Daerah-daerah utama penghasil gula di Pulau Jawa ada di Pantai Utara Jawa yang memiliki sistem pengairan sawah yang sangat baik, yaitu antara Keresidenan Cirebon sampai Semarang, kemudian di Selatan Gunung Muria hingga Juwana. Kemudian daerah kesultanan (varstenlanden) termasuk produsen gula yang baik pula. Menyusul setelah itu keresidenan Madiun, Kediri, dan Basuki di Jawa Timur. Selain itu, wilayah Probolinggo, Pasuruan, Malang, dan daerah-daerah Surabaya hingga Jombang di Pantai Utara Jawa juga termasuk produsen gula utama Jawa (Leirissa, 2012: 65). Adapun perkembangan ekspor Hindia Belanda tahun 1874-1914 dapat dilihat pada Tabel 1.1. Berdasarkan Tabel 1.1. di atas terlihat bahwa terjadi perkembangan luar biasa ekspor Hindia Belanda pada periode tahun 1874-1914. Sebagai suatu catatan, perlu diingat bahwa setelah 1885 perkembangan tanaman perdagangan mulai berjalan seret diakibatkan jatuhnya harga gula dan kopi di pasaran internasional. Jatuhnya harga gula di pasar dunia diakibatkan di Eropa mulai dilakukan penanaman gula bit (beet sugar) sehingga mereka tidak perlu lagi mengimpor dari Hindia Belanda. Pada tahun 1891 harga tembakau di pasar internasional juga jatuh sehingga mengancam kelangsungan hidup 
HISTORIA: Jurnal Program Studi Pendidikan Sejarah Volume 7 (2) 2019

ISSN 2337-4713 (E-ISSN 2442-8728)

perkebunan-perkebunan tembakau di

Deli, Sumatera Timur.

Tabel 1.1. Ekspor Hindia Belanda, 1874-1914 (dalam jutaan Gulden)

\begin{tabular}{c|c|c|c}
\hline Komoditi & 1874 & 1914 & Perubahan (\%) \\
\hline Gula & 50 & 183 & +266 \\
Kopi & 68 & 23 & -66 \\
Teh & 3 & 27 & +800 \\
Rempah-Rempah & 6 & 14 & +133 \\
Tembakau & 11 & 64 & +482 \\
Kopra & 0 & 61 & + \\
Timah & 5 & 41 & 720 \\
Minyak Bumi & 0 & 137 & ++ \\
Karet & 0 & 27 & ++ \\
Asal: & & & +150 \\
Jawa+Madura & 144 & 360 & +1.196 \\
Luar Jawa & 25 & 324 & +305 \\
Hindia Belanda & 169 & 685 & $(2016: 53)$ \\
\hline
\end{tabular}

Sumber: Van Zanden \& Marks (2012), h. 85 dalam Boediono (2016: 53)

Krisis perdagangan tahun 1885 juga ikut memukul bank-bank perkebunan (cultur banken) yang meminjamkan uang ke berbagai perusahaan perkebunan. Akibat jatuhnya usaha perkebunan, maka secara otomatis ikut jatuh pula bankbank perkebunan. Selain itu, krisis perdagangan pada tahun 1885 mengakibatkan terjadinya reorganisasi dalam kehidupan ekonomi Hindia Belanda. Perkebunan-perkebunan besar tidak lagi sebagai usaha milik perseorangan. Akan tetapi, direorganisasi menjadi perseroanperseroan terbatas.

Pemimpin perkebunan bukan lagi pemiliknya secara langung tetapi oleh seorang manajer. Artinya seorang yang digaji dan langsung bertanggungjawab kepada direksi perkebunan yang biasa dipilih dan diangkat oleh pemilik saham. Begitu juga dengan bank perkebunan (cultur banken) juga tetap melanjutkan usahanya sebagai pemberi kredit kepada perkebunan-perkebunan. Namun, setelah krisis 1885 mereka pun juga mengadakan pengawasan atas operasi perkebunan-perkebunan besar tersebut.

Pada akhir abad ke-21 terjadi perkembangan baru dalam kehidupan ekonomi di Hindia Belanda. Sistem liberal murni dengan persaingan bebas mulai ditinggalkan dan digantikan dengan suatu tata ekonomi yang lebih terpimpin. Kehidupan sosial-ekonomi Hindia Belanda khususnya di Jawa mulai dikendalikan oleh kepentingankepentingan finansial dan industrial di negeri Belanda. Kewenangankewenangan tidak lagi diberikan kepada pemimpin perkebunan-perkebunan besar 
yang berkedudukan di Jawa (Daliman, 2012: 52-53).

\section{PENUTUP}

\section{Simpulan}

Perkembangan sistem perkebunan di Hindia Belanda tidak lepas dari pasang-surutnya dinamika ekonomipolitik di negeri Belanda. Sebagai wilayah jajahan Belanda, di Hindia Belanda pada waktu itu dikenal dua sistem perkebunan yang menonjol, yaitu sistem perkebunan "negara” (18301870) dan sistem perkebunan swasta “liberal” (pasca diterapkannya Agrarische Wet 1870). Perkembangan swastanisasi perkebunan di Hindia Belanda mendapatkan momennya sejak diberlakukannya Agrarische Wet 1870.Agrarische Wet 1870 menjadi landasan yuridis-formil masuknya investasi asing dalam industri perkebunan di Hindia Belanda. Pemodal swasta diberikan hak erfpacht (hak guna usaha)selama 75 tahun oleh pemerintah Belanda untuk membuka lahan perkebunan baru di Hindia Belanda. Selama periode antara 1870 hingga 1942 perkembangan modal swasta dalam sektor perkebunanpasca pemberlakuan Agrarische Wet 1870 mendominasi perekonomian di Hindia Belanda.

Khusus di Pulau Jawa, perkembangan paling mencolok dari swastanisasi perkebunan adalah perkembangan pesat industri gula (barang dagangan penting dari Hindia
Belanda pada waktu itu). Dengan tersedianya modal swasta dalam jumlah besar. Perkebunan-perkebunan gula dan beberapa perkebunan lainnya dapat mengimpor mesin dan berbagai peralatan yang dapat meningkatkan produktifitas produksinya. Misalnya dalam hal perkebunan gula, perluasan lahan produksi dan kemajuan teknik produksi yang diintroduksi dalam industri ini menyebabkan kenaikan produksi yang pesat. Meskipun di sisi lain terjadi penurunan setelah resesi 1884-1885, dengan perbaikan yang terjadi secara lambat pada dasawarsa 1890-an. Perkembangan prosfek perkebunan di Hindia Belanda terus berlangsung hingga meletusnya Perang Dunia I.

\section{Saran}

Penelitian mengenai sejarah sosial ekonomi di Indonesia sangat menarik. Banyak sekali objek kajian yang bisa dikaji, terutama mengenai kondisi sosial ekonomi Indonesia pada masa penjajahan Hindia Belanda. Salah satunya ialah penelitian ini yang membahas konsep dan dampak penerapan Agrarische Wet 1870 terhadap perkembangan perkebunan di Indonesia khususnya di Pulau Jawa. Agrarische Wet 1870 inilah yang kemudian menjadi pintu gerbang utama swastanisasi perkebunan di Indonesia jelas berpengaruh besar terhadap 
HISTORIA: Jurnal Program Studi Pendidikan Sejarah Volume 7 (2) 2019

ISSN 2337-4713 (E-ISSN 2442-8728)

perubahan sosial dan ekonomi masyarakat Indonesia khususnya Pulau

Jawa pada saat itu dan masa sekarang.

\section{DAFTAR PUSTAKA}

Abdurrahman, Dudung. (2011). Metodelogi Penelitian Sejarah Islam. Yogyakarta: Ombak.

Achdian, Andi. (2008). Tanah Bagi yang Tak Bertanah: Landreform Pada Masa Demokrasi Terpimpin. Bogor: Kekal Press.

Anggraini, Gita. (2016). Islam dan Agraria Telaah Normatif dan Historis Perjuangan Islam dalam Merombak Ketidak Adilan Agraria. Yogyakarta: STPN Press.

Boediono. (2016). Ekonomi Indonesia: Dalam Lintasan Sejarah. Bandung: Mizan.

Daliman, A. (2012). Sejarah Indonesia Abad XIX-Awal Abad XX: Sistem Politik Kolonial dan Administrasi Pemerintahan Hindia Belanda. Yogyakarta: Ombak.

Kahin, George McTuran. (1952). Nationalism and Revolutin in Indonesia. 2013. Terjemahan oleh Tim Komunitas Bambu. Jakarta: Komunitas Bambu.

Leirissa, R.Z dkk. (2012). Sejarah Perekonomian Indonesia. Yogyakarta: Ombak.

Marzuki, A.B Yas. (2004). Metodelogi Penelitian Sejarah dan Historiografi. Palembang: Fakultas Keguruan dan Ilmu Pendidikan Universitas Sriwijaya.

Oudejans, Jan H.M. (1999). Development of Agriculture in Indonesia. 2006. Terjemahan oleh Edhi Martono. Yogyakarta: Gadjah Mada University Press.
Padmo, Soegijanto., dan Djatmiko, Edhie. (1991). Tembakau Kajian Sosial Ekonomi. Yogyakarta: Aditya Media.

Poesponegoro, Marwati Djoened., dan Notosoesanto, Nugroho. (2008). Sejarah Nasional Indonesia IV. Jakarta: Balai Pustaka.

Rachman, Noer Fauzi.(2012). Land Reform Dari Masa Ke Masa. Yogyakarta: Tanah Air Beta dan Konsorsium Pembaruan Agraria (KPA).

Ricklefs, Merle Calvin. (1981). A History of Modern Since c. 1200 Fourth Edition. 2008. Tim Penerjemah Serambi. Jakarta: Serambi Ilmu Semesta.

Ricklefs, Merle Calvin dkk. (2013). Sejarah Asia Tenggara Dari Masa Prasejarah Sampai Kontemporer. Jakarta: Komunitas Bambu.

Salim, M. Nazir dkk. (2014). Dari Dirjen Agraria Menuju Kementrian Agraria: Perjalanan Kelembagaan Agraria, 1948-1965. Yogyakarta: STPN Press.

Sembiring, Julius. (2018). Dinamika Pengaturan dan Permasalahan Tanah Ulayat. Yogyakarta: STPN Press.

Shohibuddin, Mohamad (Ed.). (2012). Pembentukan Kebijakan Reformasi Agraria, 2006-2007 Bunga Rampai Perdebatan. Yogyakarta: STPN Press.

Shohibuddin, Mohamad., dan Luthfi, Ahmad Nashih. (2010). Land Reform Lokal A La Ngandagan: Inovasi Sistem Tenurial Adat Sebuah Desa Jawa, 1947-1964. Yogyakarta: STPN Press.

Soesangobeng, Herman. (2012). Filosofi, Asas, Ajaran, Teori, dan Agraria. Yogyakarta: STPN Press. 
Tauchid, Muchammad. (2009). Masalah Agraria Sebagai Masalah Penghidupan dan Kemakmuran Rakyat Indonesia. Yogyakarta: STPN Press.

Vollenhoven, Cornelis van. (1923). De Indonesier en Zijn Ground. 2013. Terjemahan oleh Soewargono. Yogyakarta: STPN Press.

Wiradi, Gunawan. (2000). Reformasi Agraria Perjalanan yang Belum Berakhir. Yogyakarta: INSIST Press.

Wiradi, Gunawan. (2009). Seluk Beluk Masalah Agraria, Reforma Agraria dan Penelitian Agraria. Yogyakarta: STPN Press.

Wodowati, Dyah Ayu dkk. (2014). Pengakuan dan Perlindungan Hak Atas Tanah Masyarakat Hukum Adat di Kawasan Hutan. Yogyakarta: STPN Press.

Tim Riset Sistematis STPN. (2010). Pengembangan Kebijakan Agraria untuk Keadialan Sosial, Kesejahteraan Masyarakat, dan Keberlanjutan Ekologis.

Yogyakarta: STPN Press. 